\title{
Effect of Acrylamide on Liver Proteins Expression in Mice
}

\author{
Ahlam S. Al-Azkawi ${ }^{1}$, Saif N. Al-Bahry ${ }^{1}$, Ibrahim Y. Mahmoud ${ }^{2} \&$ Michael J. Barry $^{1}$ \\ ${ }^{1}$ Deaprtment of Biology, College of Science, Sultan Qaboos University, Muscat, Oman \\ ${ }^{2}$ Department of Biological Sciences and Chemistry, Universty of Nizwa, Nizwa, Oman \\ Correspondence: Saif N. Al-Bahry, Deaprtment of Biology, College of Science, Sultan Qaboos University, \\ Muscat, Oman. E-mail: snbahry@squ.edu.om
}

Received: August 1, 2013 Accepted: September 6, 2013 Online Published: September 13, 2013

doi:10.5539/jfr.v2n5p132 URL: http://dx.doi.org/10.5539/jfr.v2n5p132

\begin{abstract}
Carbohydrate rich food cooked at high temperature can lead to the formation of acrylamide. The aim of this investigation is to analyze the proteomics of mice liver in response to acrylamide intoxication since the liver is the major site of acrylamide detoxification and metabolism. The liver protein pattern from sodium dodecyl sulfate polyacrylamide gel electrophoresis (SDS-PAGE) treated mice with acrylamide in drinking water for 9 weeks did not show variations from the control. However, analysis by 2-D gel of liver proteins from mice treated with $0.5 \mu \mathrm{g}$ acrylamide/ $\mathrm{kg}$ for 9 weeks showed variations in protein expression. At least 10 protein spots were significantly affected $(\mathrm{T}>2)$ by the acrylamide treatment. The affected proteins were identified using MALDI TOF/TOF and mass searches through Mascot. These proteins were up-regulated or down-regulated depending on their physiological function. Probably the proteins are involved in detoxification of acrylamide or cell protection. The data from this study shows that proteomics is a valuable tool for assessing acrylamide toxicity in the affected tissues.
\end{abstract}

Keywords: acrylamide, toxicity, proteomics, mouse

\section{Introduction}

Acrylamide is widely used in various chemical industries such as dye, ore and water. It is also used in laboratories for separation of macromolecules in electrophoresis. Acrylamide has been extensively studied and there is a large database on its toxicity and pharmokinetics indicating that this compound is carcinogenic. Neurotoxicity has been reported in humans, but without carcinogenic effect (Deng et al., 1993).

In the last decade, the Swedish National Food Administration reported that high levels of acrylamide may be present in human's diet. Rats fed with fried food were found to have elevatedacrylamide concentration. High acrylamide levels were found in fried or baked starchy foods such as cereals, biscuits, French fries and potato chips (Tareke et al., 2002).

Sub-acute toxic effects were experienced by individuals drinking well water contaminated with acrylamide. Symptoms of toxicity include disorientation, confusion, memory disturbances, truncal ataxia and hallucinations. In many instances typical clinical symptoms from the exposure of humans to acrylamide was reported. These include foot weakness, generalized fatigue, skin irritation, and sensory changes which resulted in dysfunction of either the peripheral or the central nervous system (World Health Organization "WHO", 2003).

The effect of acrylamide on chromosomal aberrations of 25 workers exposed to acrylamide-containing grout during tunnel work revealed that there were no aberrations or chromosomal breaks, but there was an increase in frequency of chromatid gaps (Kajuus et al., 2005).

Genetic studies on thetoxicity of acrylamide were evaluated in vivo and in vitro assays. Mutation frequency was not reported at non-cytotoxic levels when mammalian cells were incubated with acrylamide (Tsuda et al., 1993). However, molecular studies of mutants with thymidine kinase (TK) indicated that acrylamide caused loss of heterozygosity mutation (Koyama et al., 2006).

In vitro studies of acrylamide in Chinese hamster V79 cells caused aberration of chromosomes (Tsuda et al., 1993). Nesterova et al. (1999) revealed that the number of cells with chromosome aberrations in BALB/c and C57B1/6 increased significantly, and was found to have no effect in CBA mice. Other acrylamide carcinogenicity studies in rats and mice revealed that it caused tumors in multiple sites (Bull et al., 1984). 
Investigations on the effect of acrylamide on proteins have mainly been confined to neurotoxicity in the central nervous system (Li et al., 2006; Barber et al., 2007). Other investigators haveanalyzed cytoskeletal proteins in plasma as potential biomarkers of acrylamide neurotoxicity (Yi et al., 2006). Neurotoxicity related to proteins in plasma and other tissues, including brain and liver, were also reported by Yousef and El-Demerdash (2006).

Li et al. (2006) reported that tissues taken from peripheral and central nervous systems after exposure to acrylamide revealed sub-chronic expression of apoptotic-related proteins. Barber et al. (2007) in their study on rats showed that acrylamide intoxication caused a progressive reduction in many nerve terminal proteins.

In male rats exposed to different concentrations of acrylamide, lipid peroxidation and selective enzyme activities were affected and resulted in proteins level reduction in tissues and plasma (Yousef \& El-Demerdash, 2006). Odland et al., in 1994, reported that the rate of protein synthesis decreased in response to various acrylamide concentrations. A significant decrease in body weight in mice treated with various concentrations of acrylamide in comparison to control animals. This is probably the result of breakdown of tissue and plasma proteins (Yousef \& El-Demerdash, 2006).

The aim of this study is to investigate protein expression pattern in mice liver upon ingestion of acrylamide in drinking water using 2D-gel electrophoresis and to identify the affected liver proteins using MALDI TOF/TOF.

\section{Method}

\subsection{Animal \& Treatment}

Two-months old C57BL/6 male mice were used for this study. Each mouse was caged individually and kept at a temperature ranging $21-24{ }^{\circ} \mathrm{C}$ and relative humidity at $40-60 \%$ with $12 \mathrm{~h}$ light-dark cycle. This cycle is essential for the rest/awake pattern in order to obtain normal metabolic condition. Mice were fed with diet containing all nutritional necessities. After one week of acclimation mice were treated as follow: group 1 served as a control, received drinking water only, group 2 was treated with $0.5 \mu \mathrm{g} / \mathrm{kg}$ body weight of acrylamide in drinking water according to the method of Yousef and El-Demerdash (2006).

After every 3 weeks, 4 mice from each treated group were sacrificed by decapitation. The liver from each mouse was removed for general gross observation and frozen in liquid nitrogen for the extraction of protein.

\subsection{Protein Extraction and Determination}

The procedure for protein extraction was done following Fountoulakis et al. (2000) protocol with some modifications. Liver tissue $(0.3 \mathrm{~g})$ was suspended in polycarbonated centrifuge tubes (BECKMAN, USA) containing $1 \mathrm{ml}$ sample buffer mixed with $7 \mathrm{M}$ urea (BDH, UK), $40 \mathrm{mM}$ Tris (SIGMA, USA), 4\% CHAPS (SIGMA, USA), 2 Mthiourea (BDH, UK), 1 mM EDTA (BDH, UK), 10 mM Dithioteritol (DTT) (SIGMA, USA) and $1 \mathrm{ml}$ of protease inhibitor cocktail (SIGMA, USA). The Tissue Tearor (BIOSPEC PRODUCTS, INC) was used to homogenize the suspension for approximately 1 minute, sonicated for 30 seconds and centrifuged at $150 \mathrm{~K} \mathrm{X} \mathrm{g}$ for 45 minutes at $10^{\circ} \mathrm{C}$. Samples were kept at $4{ }^{\circ} \mathrm{C}$ during preparation. After the first centrifugation, 2 $\mathrm{ml}$ of the supernatant was transferred into two $1.5 \mathrm{ml}$ microcentrifuge tubes. The samples were further centrifuged at $14 \mathrm{~K} g$ for 15 minutes at $4{ }^{\circ} \mathrm{C}$. Concentration of total protein samples was determined according to Lawry et al. (1951), using the DC microplate protein assay (BIORAD, USA). The remaining protein samples were kept in $-70{ }^{\circ} \mathrm{C}$ for further electrophoresis use.

\subsection{Protein Electrophoresis}

\subsubsection{SDS-PAGE}

After protein determination, all samples were prepared for SDS-PAGE following the method described by Laemmli (1970). Stacking gel concentration was 5\% in 0.5M Tris (pH 6.8) buffer. Resolving gel concentration was $12 \%$ in $1.5 \mathrm{M}$ Tris (pH 8.8) buffer. Electrophoresis was done with Hoefer SE 600 Series (Amersham Pharmacia Biotech, USA). Loading sample of $50 \mu \mathrm{L}$ with final protein concentration of $35 \mu \mathrm{g} / \mu \mathrm{L}$ was prepared in sample buffer containing $0.125 \mathrm{M} 0.5 \mathrm{M}$ Tris-HCl, pH 6.8 (ICN Co.), $25 \%$ Glycerol (Merck), 0.4\% SDS , $0.02 \%$ bromophenol blue $0.5 \%, 2 \%$ mercaptoethenol. Samples were kept at $95{ }^{\circ} \mathrm{C}$ for 4 minutes to denature the proteins. Samples, along with SDS-PAGE molecular weight (MW) standards broad range (myosin, $\beta$-galactosidase, phosophorylase $\mathrm{b}$, serum albumin, ovalbumin, carbonic anhydrase, trypsin inhibitor, lysozym and aprotinin with molecular weights of 200, 116.25, 97.4, 66.2, 45, 31, 21.5, 14.4 and 6.5 Kda respectively), were loaded into each well. The gels were run at 200 volts for 20 minutes then 50 volts overnight in a tank buffer containing running buffer, $\mathrm{pH} 8.3$ consisting of $0.025 \mathrm{M}$ Tris, $0.192 \mathrm{M}$ glycine and $0.1 \%$ SDS.

Gels were stained by blue silver staining according to the method of Candiano et al. (2004). Gels were soaked in fixation solution mixed with $40 \%$ ethanol and 10\% acetic acid for 15-30 minutes. Then gels were washed in 2 
changes of water 10 minutes each time and staining solution (10\% ammonium sulfate, $10 \%$ phosphoric acid, $20 \%$ methanol and $1.2 \%$ Coomassie blue G-250) was added to completely cover the gels overnight. Gels were then washed in several changes of water until all Coomassie particles were removed and clear background was obtained. All staining steps were performed on an orbital shaker at room temperature.

\subsubsection{Two Dimensional (2-D) Gel Electrophoresis}

Protein samples from the 9 weeks acrylamide treatment were further analyzed by 2-D gel electrophoresis. $1.5 \mathrm{mg}$ protein samples were applied on $17 \mathrm{~cm}$ immobilized pH 4-7 gradient (IPG) strips (BIORAD, USA). IPG strips were prepared following the manufacturer's recommendations.

The protein sample and the rehydration buffer were mixed by pipetting and the contents were centrifuged at $14 \mathrm{~K}$ $\mathrm{X} \mathrm{g}$ for 15 minutes and were then applied on the IPG strips, covered by mineral oil and left at room temperature for 15 hours. The strips were then subjected to isoelectric focusing started at $250 \mathrm{~V}$ for 20 minutes and $10,000 \mathrm{~V}$ for 2.5 hours, then rapidly increased by $10000 \mathrm{~V} /$ hour to reach maximum of 50,000 V. The following day, each strip was incubated in $6 \mathrm{ml}$ equilibration buffer containing 2\% DTT and equilibrated in buffer consisting of $6 \mathrm{M}$ urea, $2 \% \mathrm{SDS}, 50 \mathrm{mM} 1.5 \mathrm{M}$ Tris/HCL, $\mathrm{pH} 8.8$, and $20 \% \mathrm{v} / \mathrm{v}$ glycerol for 20 minutes with gentle agitation. The contents were then incubated for an additional 20 minutes and treated with a second equilibration buffer consisting of the base buffer and $2.5 \%$ iodoacetamide.

The second dimension separation of the strips was performed on 15\% SDS-PAGE of $1 \mathrm{~mm}$ thickness. Molecular weight protein markers (Fermentas Life Sciences, UK) were run along with the treated IPG strips. The gels were run in a PROTEAN II xi Cell apparatus (BIORAD, USA) accommodating 2 gels at $16 \mathrm{~mA} /$ gel for 30 minutes and $24 \mathrm{~mA} / \mathrm{gel}$ for 5 hours. Gels were stained by blue silver stain previously described.

Gels were scanned in the GS-800 Calibrated Densitometer and electronic images of the gels were recorded using Quantity one-4.4.1 software (BIORAD, USA). Protein spots were analyzed using the Image Master 2D Platinum 6.0 (Swiss Institute of Bioinformatics). Manual editing and matching of spots was performed. Protein changes and matches between the control class and treatment class were sorted out by overlap ratio of spot $\%$ volume between the 2 classes.

\subsection{Matrix-Assisted Laser Adsorption/Ionization Mass Spectroscopy Time of Flight (MALDI TOF/TOF)}

\subsubsection{In-gel Digestion}

Protein spots from 2-DE gels were removed manually. The gels were dried completely in 96 wells v-shape polypropylene plates. In-gel digestion was conducted using the Ettan Spot Handling Workstation (GE Healthcare, UK). Each gel plug was soaked in $100 \mu \mathrm{L}$ washing solution $\left(50 \% \mathrm{MeOH}, 50 \mathrm{mM} \mathrm{NH} \mathrm{HCO}_{3}\right)$ for three times. The gel plugs were further washed twice in $75 \%$ CAN and then dried. Samples were then re-hydrated by the addition of freshly prepared trypsin solution ( $0.5 \mu \mathrm{g}$ modified porcine trypsin in $\left.25 \mu \mathrm{L} 20 \mathrm{mM} \mathrm{NH}_{4} \mathrm{HCO}_{3}\right)$, and then incubated for $240 \mathrm{~min}$ at $37^{\circ} \mathrm{C}$. Peptides were extracted from the gel plugs, by washing twice in $100 \mu \mathrm{L}$ of $50 \%$ ACN, $0.1 \%$ Trifluoroacetic acid (TFA). Then extracted peptides were transferred in solution to a 96-well-plate. Then the samples were dried.

\subsubsection{MALDI TOF/TOF MS}

Tryptic peptides were re-suspended in $3 \mu \mathrm{L}$ of $50 \%$ ACN, $0.1 \%$ TFA. $0.3 \mu \mathrm{L}$ of re-suspended tryptic peptides were spotted onto a steel Applied Biosystems 192 sample MALDI target plate. The samples, while still wet, were mixed with $0.3 \mu \mathrm{L}$ of a $90 \%$ saturated $\alpha$-cyano-4-hydroxycinnamic acid (CHCA) in $50 \%$ ACN, $0.1 \%$ TFA. After desiccation, the samples were analyzed in MALDI TOF/TOF MS (4700 Proteomics Analyzers, Applied Biosystems, UK). Up to 10 precursor peptides were analyzed using MS followed by MS/MS. Internal calibration for each sample was conducted in reference to specific autolytic fragments of trypsin. The PMF and MS/MS results were compared automatically using Mascot software search engine (Matrix Science, UK) in the NCBI non-redundant database. The settings of mass tolerance for 1.2 Da parent and 0.5 Da fragment ions were applied. Two modifications and one missed cleavage with trypsin (carboxamidomethylation of cysteine and oxidation of methionine) were used for search settings. Statistical confidence limits of $95 \%$ were used for identification of proteins.

\section{Results}

\subsection{Protein Electrophoresis}

\subsubsection{SDS-PAGE Pattern}

The SDS-PAGE pattern of liver proteins from control mice and those treated with $0.5 \mu \mathrm{g} / \mathrm{kg}$ body weight of acrylamide for 3, 6 and 9 weeks are shown respectively in Figure 1(a-c). Four replicate samples, control and 
treated, were loaded in the gels. The SDS-PAGE in the control and acrylamide treated mice for 9 weeks did not show any variation.

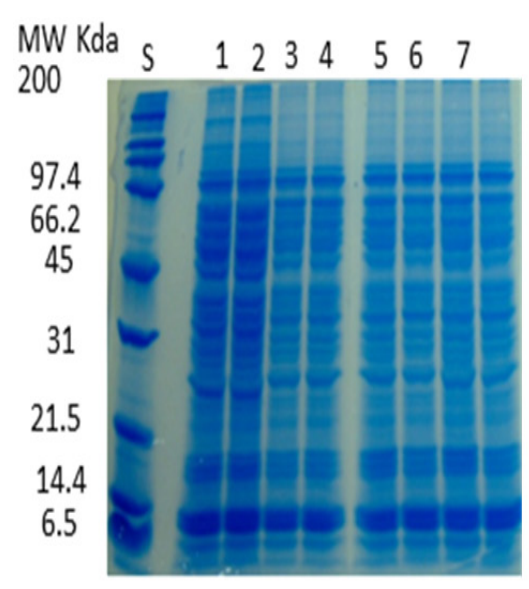

a

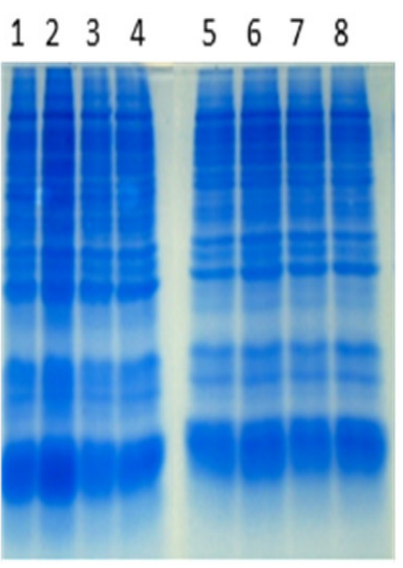

b

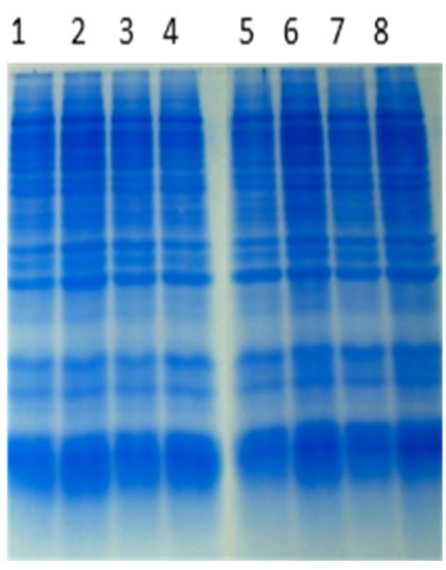

c

Figure 1. The SDS-PAGE pattern of liver proteins from mice treated with $0.5 \mu \mathrm{g}$ acrylamide $/ \mathrm{kg}$. S: molecular weight standard. Lanes 1-4: control, 5-8: $0.5 \mu \mathrm{g}$ acrylamide/kg. (a) 3 weeks, (b) 6 weeks and (c) 9 weeks

\subsection{2-D Electrophoresis Map}

The 2-D gel electrophoresis was used for proteins separation into spots and then stained with blue silver technique. Figure 2 shows representative examples of the 2D map of liver proteins from the control and treated mice.

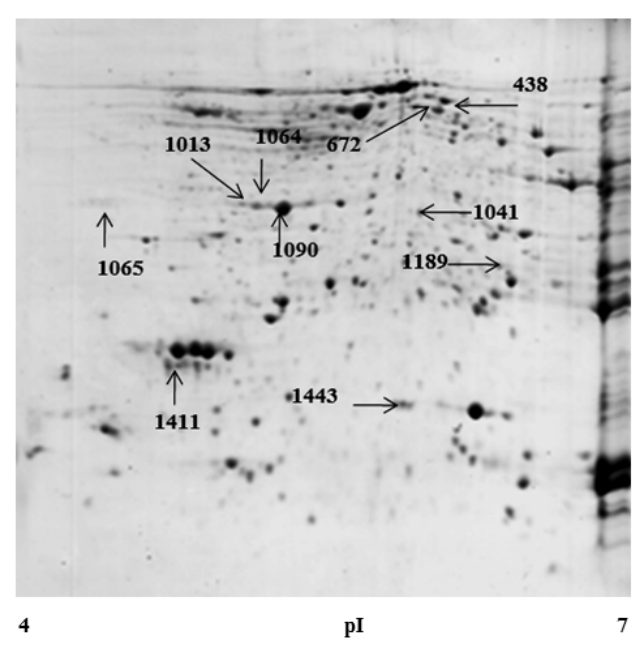

a

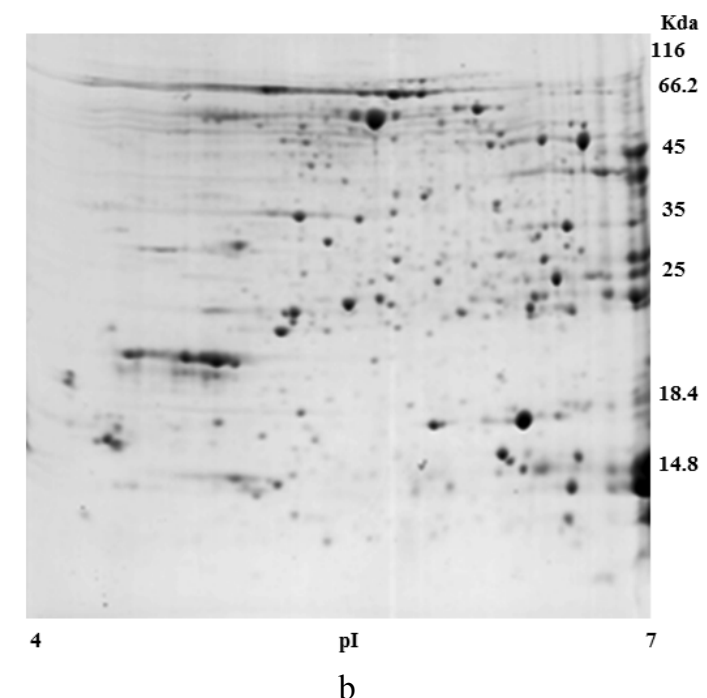

b

Figure 2. Master 2D map of liver proteins from (a) control and (b) $0.5 \mu \mathrm{g}$ acrylamide/kg treated mouse liver proteins illustrating the spot variations between control and treatment groups

Spot analysis by the Image Master 2D Platinum 6.0 (Swiss Institute of Bioinformatics) reported significant variations in the expression level of at least 10 protein spots (Student $t$-Test $>2$ ). The proteins were identified using MALDI TOF-TOF and mass searches through Mascot. The identification was performed covering proteins of molecular weight ranging from 6 to $66 \mathrm{~K}$ da and $\mathrm{pH}$ ranges of 4-7. The spots were named by their Inter-Class match ID number. The proteins which match ID 672, 1013, 1041, 1064, 1065, 1090, 1411 and 1443 were down-regulated while spots 438 and 1189 were up-regulated in response to intoxication with $0.5 \mu \mathrm{g}$ acrylamide/kg. In Table 1, the relative expression levels of the identified affected proteins from acrylamide 
treatment are listed with the MW and the pI values.

Table 1. Expression levels of the proteins affected by acrylamide treatment

\begin{tabular}{lccl}
\hline Protein Name (Match ID) & MW Kda (PI) & $\begin{array}{c}\text { Control } \\
(\mathrm{mean} \pm \mathrm{SD})\end{array}$ & $\begin{array}{l}\text { Experimental } \\
(\mathrm{mean} \pm \mathrm{SD})\end{array}$ \\
\hline PD-I, A3 (438) & $56.380(5.71)$ & $0.16 \pm 0.05$ & $0.7 \pm 0.22$ \\
SeBP-1 (672) & $52.618(5.80)$ & $0.08 \pm 0.05$ & 0 \\
RC-SMP30 (1013) & $34.152(5.01)$ & $2.23 \pm 0.38$ & $0.73 \pm 0.46$ \\
Trpg 5 [Musmusculus] (1041) & $27.087(6.19)$ & $0.28 \pm 0.18$ & $0.01 \pm 0.00$ \\
Unnamed protein product (1064) & $33.892(5.1)$ & $0.02 \pm 0.00$ & 0 \\
SP 1 (1065) & $26.802(4.75)$ & $0.03 \pm 0.01$ & 0 \\
CQ 9 homolog (1090) & $35.231(5.6)$ & $0.06 \pm 0.00$ & 0 \\
GST yc class-alpha member 3 (1189) & $30.315(6.59)$ & $0.10 \pm 0.01$ & $0.34 \pm 0.16$ \\
MUPI (1411) & $20.872(5.02)$ & $0.06 \pm 0.02$ & 0 \\
Cu/Zn SOD (1443) & $15.922(6.03)$ & $0.16 \pm 0.03$ & $0.04 \pm 0.03$
\end{tabular}

Protein levels are expressed as the mean value \pm SD of spot \% volume. Means and standard deviations were calculated for 3 animals in each group.

\section{Discussion}

This study focused mainly on the analyses of proteomics of mice liver in response to acrylamide toxicity. Previous studies mainly focused on proteins that were related to neurotoxicity (Yi et al., 2006; Yousef \& El-Demerdash, 2006; Barber et al., 2007).

The SDS-PAGE pattern of liver proteins from the control and experimental mice treated with $0.5 \mu \mathrm{g}$ acrylamide in drinking water for 9 weeks did not reveal any significant difference between the two groups. However, using more sensitive technique (the 2-D gel) with the same two groups revealed variation in the protein expression. At least 10 protein spots were significantly affected by the acrylamide treatment $(\mathrm{T}>2)$.

Some of the proteins were unidentified because, most likely, no such mouse protein sequence has been registered in the available databases. This is the case with protein with Match ID 1064 which was identified as unnamed protein product. More studies will be needed to identify this protein and its physiological function and possible role in acrylamide toxicity.

Regardless of unidentified protein spots (i.e. unidentified by the database), the following will address the general function and role of the known proteins in addition to their possible role and involvement in acrylamide toxicity.

In this study, the Major Urinary Protein I (MUPI) from the treated mice liver was down-regulated, thus showing less expression from that of the controls. MUP isomers are small soluble proteins belonging to the lipocalin family. MUP are known to bind to pheromonal ligands, therefore assisting the pheromone communication system that ranges from brief behavioral changes, such as inter-male aggression and dominance signaling, to a longer periods of physiological change characterized by estrus synchrony, puberty acceleration, or puberty delay.

The expression of some MUPs occurs in liver and kidney at the sites of pheromone excretion (Robertson et al., 1996). In addition, mRNA of some MUPs was found in the nasal mucosa and lacrimal, submaxillary sublingual, and parotid glands (Shahan et al., 1987). Different MUP isoforms encoded by various genes were found in laboratory inbred mice strains (Shahan et al., 1987). The isoform profile varied significantly in reference to gender, strain, and hormone levels (Robertson et al., 1996). The roles of most MUP isoforms remain unknown. Timm et al. (2001) stated that the isoforms may bind differentially and release various pheromones regulating MUP levels. In this case the levels of available pheromones are indirectly regulated in animals.

It is unclear if there is a causal connection between the variations observed in MUP isomers in week-nine treated mice and exposure to acrylamide. However, one study (Larsen et al., 1990) reported the involvement of the MUPs in metabolism and excretion of lipophilic xenobiotic compounds. The metabolite of a polychlorinated biphenyl of methylsulphonyl serves as a ligand for MUP in mice.

The RC senescence marker protein-30 (SMP30) is another protein in this investigation that was also found to be 
down-regulated. This calcium-binding protein with a molecular weight of 34-kd protein is mainly expressed by hepatocytes and renal tubular epithelia. The SMP30 decreases with aging in an androgen-independent manner. SMP30 activates $\mathrm{Ca}^{2+}$ efflux in hepatic cells (HepG2) by calmodulin-dependent $\mathrm{Ca}^{2+}$ pump as well as the renal tubular epithelial cells. The SMP30 protect the cells from injuries from high intracellular $\mathrm{Ca}^{2+}$ concentrations (Fujita et al., 1998). Xue et al. (2000) reported that in vitro performance of the SMP30 stimulates uptake of ATP-dependent $\mathrm{Ca}^{2+}$ in rat liver mitochondria and also stimulates activity of $\mathrm{Ca}^{2+}$ pump in mitochondria of renal cortex.

Proteomic analysis revealed that SMP30 levels in primary hepatocyte cultures increased tumor necrosis factor- $\alpha$ (TNF- $\alpha$ ) (Chevalier et al., 2000). The TNF- $\alpha$ stimulates apoptosis in mammalian cells as a result of increasing intracellular $\mathrm{Ca}^{2+}$ levels (Kong et al., 1997). In addition, the SMP30 prevented death of mammalian cells by elevating the activity of plasma membrane $\mathrm{Ca}^{2+}$ pump (Fujita et al., 1998; Inoue et al., 1999).

In this study SMP30 was down-regulated in response to $0.5 \mu \mathrm{g}$ acrylamide $/ \mathrm{kg}$ for 9 weeks possibly suggesting that acrylamide may cause suppression of this protein and therefore causing the cells to go into possible harmful responses, including necrosis.

The expression level of selenium-binding protein (SeBP) in this study was also found to be down-regulated. $\mathrm{SeBP}$ is a cytosolic protein found in a different mouse and rat tissues especially in the kidneys, mammary glands, testes, ovaries, and liver of mice (Ishida et al., 2002). The expression level in these organs is correlated with low frequency of cancer (Yang \& Sytkowski, 1998).

Porat et al., (2000) reported that the physiological role of selenium/acetaminophen-binding protein (SeBP) is unclear. However, it was suggested that SeBP may participate in late stages of intra-Golgi transport. Another class of SeBP may be involved in cell damage. It has been postulated that this protein could act as a "sensor" function and that once in the nucleus, it could trigger the transcription genes needed to either repair the damaged cell or drive it into necrosis/apoptosis (Hong et al., 1994). SeBP may have a similar role, especially as it has been suggested that SeBP expression level correlates with low frequencies of cancer. The down-regulation in the expression level of SeBP in this study suggests that its synthesis has been affected by the acrylamide at low dosage. These assumptions will require more research effort to be proven, because if they are true this could indicate that even lower levels of acrylamide can increase the frequency of cancer.

RC Senescence marker protein-30 (RC-SMP30) is another protein that was also found in this study to be down-regulated. RC-SMP30 is a calcium-binding protein that decreases in an androgen-independent manner with aging (Fujita et al., 1992a,1992 b, 1996).

$\mathrm{RC}$ Senescence marker protein-30 is a calcium-binding protein that decreases in an androgen-independent manner with aging (Fujita et al., 1992a and b and 1996).

The coenzymes Q (CQ) are essential components of the electron transport system in mitochondria, and therefore, of extreme importance to the energy-producing systems of the cell. In this study, the concentration of this enzyme was reduced in the treated mice liver. Previously, the co-enzymes have been studied in the blood and tissues of normal humans and experimental animals, as well as in those with various pathological processes, in order to determine whether they are related to disease progression. In case of neoplasia, the level of CQ in the liver of a few cancer patients has been studied (Phillips et al., 1961) and was found to be no different from normal individuals. Similar results were obtained when the livers of tumor-bearing rats and the blood samples of cancer patients were studied (Shichiri et al., 1968). A significant decrease in the total concentration of CQ was found in the livers of rats with Walker carcinoma (Yamamoto \& Tanaka, 1967) and in mitochondria of ascites hepatoma in rats (Sugimura et al., 1962). This suggests that the down-regulation of this enzyme may indicate a possible abnormality of the liver in response to acrylamide.

Moreover, the enzyme $\mathrm{Cu}-\mathrm{Zn}$ superoxide dismutase (SOD) wasalso down-regulated by acrylamide intoxication. $\mathrm{Cu} / \mathrm{Zn} \mathrm{SOD}$ enzyme plays a major role in superoxide radicalsdismutation into hydrogen peroxide which occurs from cellular oxidative metabolism (Fridovich, 1978). Thus, Cu-Zn SOD is essential in the immune response. Up-regulation of $\mathrm{Cu}-\mathrm{Zn} \mathrm{SOD}$ would increase the potential of reactive oxygen concentration in macrophages at the inflammation stage. On the other hand, Cu-Zn SOD inhibition would reduce this capability, causing inhibition of the immune response because it would strongly reduce the release of TNF- $\alpha$. TNF- $\alpha$ is essential to activatethe immune response and inflammatory cells (Marikovsky et al., 2003). Inactivation of Cu-Zn SOD was also reported to be a cause of hepatocellular carcinoma which is a primary malignancy (cancer) of the liver (Elchuri et al., 2005).

The above affected proteins are associated with the immune system and the apoptosis mechanism which are all 
essential in protecting cells from any kind of abnormalities, including malignancy. Li et al. (2006) reported similar findings. They stated that sub-chronic exposure to acrylamide caused the expression of apoptotic-related proteins in tissues taken from the peripheral and the central nervous systems.

Trypsin is one of the best characterized serine proteases (SP) which has long been known to be produced as trypsinogen (Trpg) in the acinar cells of the pancreas (Dunn 1989). SPs are one of the major groups of secretory proteases which are important in manyphysiological processes, including blood coagulation, food digestion, control of blood pressure and fibrinolysis (Neurath, 1984). They play critical roles, not only in digestion but in tissue remodeling. They are also involved in various pathological processes, including abnormal blood coagulation, inflammation, tumor invasion, and atherosclerosis.

Trpg's are commonly found in brain, skin, in endothelial and epithelial cells, lung, esophagus, stomach, pancreas, small and large intestines, bile duct, liver, spleen and kidney (Koshikawa et al., 1998). In a study by Li et al. (2006), it was observed that the down-regulation of Trpg was involved in growth retardation due to malnutrition. This is a very interesting finding with regard to the current study where acrylamide was shown to cause down-regulation in Trpg levels that was also accompanied by a decrease in serine levels.

This may confirm the previous finding by Yousef and El-Demerdas (2006) in whichgrowthretardation was observed in animals treated with acrylamide compared to the control group.

The activities of Glutathione S-transferase (GST) and Protein disulfide isomerase (PDI) wereincreased by acrylamide-treatment in the present study.

In this study, the GST level in mice liver treated with $0.5 \mu \mathrm{g}$ acrylamide $/ \mathrm{kg}$ was found to be up-regulated. GST is a group of enzymes which are important in detoxification by conjugating with many hydrophobic and electrophilic compounds resulting in reducing glutathione (Chasseau, 1979). Up to $10 \%$ of cytosolic proteins are made from these enzymes in some mammalian organs (Boyer, 1989). GSTs are involved in the conjugation of reduced glutathione through the sulfhydryl group to electrophilic centers of substrates (Douglas, 1987). The other important enzymatic activities of the GSTs are binding to toxins and in protein transport (Litwack et al., 1971).

The in vivo detoxification of acrylamide arises mainly through enzymatic conjugation with glutathione, by GST (Dixit et al., 1982; Sumner et al., 1992). In acrylamide-treated neuroblastoma N1E 115 cells, the glutathione content is a concentration-dependent accompanied by an increased in GST activity (Odland et al., 1994). In addition, a significant increase in (GST) activity in the lung, liver, kidney and testes of rats treated with up to 500 $\mu \mathrm{g}$ acrylamide/kg has been reported (Yousef \& El-Demerdash, 2006).

The findings of the current study are similar toprevious findings. The expression level of GST in the 2-D maps has significantly increased $(\mathrm{T}>2)$ demonstrating that it was up-regulated in response to $0.5 \mu \mathrm{g}$ acrylamide $/ \mathrm{kg}$ treatment indicating its role in acrylamide detoxification. In fact, in the study of Yousef and El-Demerdash (2006), the GST levels were reported to be significantly increased only in acrylamide doses above $25 \mu \mathrm{g} / \mathrm{kg}$, thus proving the sensitivity and the efficiency of the 2-D gel analysis.

The Protein disulfide isomerase (PDI) (EC 5.3.4.1) is another protein that was found to be up-regulated in this study.

PDI is a group of the thioredoxin super-family found in abundance of the luminal protein of the endoplasmic reticulum (ER) in mammalian cells and yeast, approximately $0.8 \%$ of the total cellular protein (Freedman et al., 2002). It was initially extracted from rat liver in 1963 (Goldberger et al., 1963), and later was found in different type of tissues and organs. It was also was reported to be highly conserved in different species (Bjelland et al., 1987).

Protein Disulfide-isomerase, A3 (PD-i, A3) has various functions, including redox and chaperone activities, regulation of calcium homeostasis, and regulation of protein export from the ER for degradation. These functions are essential for maintaining a productive folding environment for many secretory proteins within the ER (Ferrari \& Soling, 1999; Freedman et al., 2002) that may be critical for the viability of the organism. The chaperone function of these proteins, and probably to varying extents redox activity as well, relies on their ability to interact non-covalently with specific peptide sequences or epitopes in substrate proteins (Freedman et al., 2002).

In the ER, it was reported that malfolded proteins and PDI are associated with over-expressed lysozyme mutants or endogenous, nascent proteins (e.g. procollagen, thyroglobulin and immunoglobulins) (Kellokumpu et al., 1997). The observed increase in the PDI levels in the mice liver in this study, after 9 weeks daily consumption of $0.5 \mu \mathrm{g} / \mathrm{kg}$ acrylamide contaminated water, suggests an increase in the cells redox. The PDI redox activity is 
related to the redox potential of glutathione ratio in the ER (Ferrari \& Soling, 1999).

Glutathione is required for acrylamide detoxification via GST (Dixit et al., 1982; Sumner et al., 1992). In this study, since the levels of GST were found to be elevated, resulting in a possible decrease in reduced glutathione, a compensating oxidation mechanism for oxidizing glutathione is probably required to have adequate levels of reduced glutathione needed for the detoxification of acrylamide in the cells. This may be a possible explanation of the elevated PD-I, A3 which is required to carry the oxidation process.

The results of this study contribute to the overall general understanding of the acrylamide effect on mice strain C57BL/6. The proteomic studies on the mice liver have clearly shown that the protein expression is effected by ingestion of acrylamide in drinking water. This effect did not appear in the SDS-PAGE while the 2D-maps have revealed some variations in the protein expression upon ingestion of acrylamide proving the efficiency and sensitivity of 2D technique over the ordinary SDS-PAGE technique.

The affected proteins were up-regulated or down-regulated depending on their physiological function whether involved in the metabolism and detoxification of acrylamide or play a role in protecting the cells from probable damage.

The change in the abundance of specific proteins in the mice treated with $0.5 \mu \mathrm{g}$ acrylamide $/ \mathrm{kg}$ may give indication of these proteins being involved in the toxic event in addition to metabolism. This assumption could be additionally supported if higher acrylamide concentrations were given to mice and further analyses by 2D gels performed by the Image Master software to compare the spot intensity of those affected proteins. That will also confirm whether the acrylamide effect on liver protein expression is dose-dependent.

The results of this study, although preliminary, show that proteomics is a valuable tool for assessing toxicity since it allows the analysis of proteins of treated animals in comparison to the control to establish treatment-related differences. More investigation is needed to establish the degree of toxicity so it can be used in different organs for measuring the toxicity range.

Further analysis, including the performance of 2-D gel using sub-cellular fractions of proteins and wider $\mathrm{pH}$ range IPG strips should be carried out. This would substantially increase the sensitivity of the method and also will allow the resolving of more proteins which were not included within the $\mathrm{pH}$ range of the IPG strips used in this study. Furthermore, future studies should also use a greater number of animals to produce more 2-D gels replicates which would eliminate the intra-individual variations and response to treatment, which is a major issue considering the biological differences between experimental animals.

\section{References}

Barber, D. S., Stevens, S., \& LoPachin, R. M. (2007). Proteomic analysis of rat striatal synaptosomes during acrylamide intoxication at a low dose rate. Toxicological Sciences, 100, 156-167. http://dx.doi.org/10.1093/toxsci/kfm210

Bjelland, S. (1987). Tissue distribution and molecular heterogeneity of bovine thiol: protein-disulphide oxidoreductase (disulphide interchange enzyme). Comparative Biochemistry and Physiology Part B. Biochemistry and Molecular Biology, 87, 907-914.

Boyer, T. (1989). The glutathione S-transferase: An update. Hepatology, 9, 486-96. http://dx.doi.org/10.1002/hep.1840090324

Bull, R. J., Robinson, M., \& Stober, J. A. (1984). Carcinogenic activity of acrylamide in the skin and lung of Swiss-ICR mice. Cancer Letters, 24, 209-212. http://dx.doi.org/10.1016/0304-3835(84)90138-1

Candiano, G, Bruschi, M., Musante, L., Santucci, L., Ghiggeri, G. M., Carnemolla, B., ... Righetti, P. G. (2004). Blue silver: a very sensitive colloidal Coomassie G-250 staining for proteome analysis. Electrophoresis, 25, 1327-33. http://dx.doi.org/10.1002/elps.200305844

Chasseaud, L. F. (1979). The role of glutathione and glutathione S-transferase in the metabolism of chemical carcinogens and other electrophilic agents. Cancer Research, 29, 175-274. http://dx.doi.org/10.1016/S0065-230X(08)60848-9

Chevalier, S., Macdonald, N., Tonge, R., Rayner, S., Rowlinson, R., Shaw, J., ... Roberts, R. A. (2000). Proteomic analysis of differential protein expression in primary hepatocytes induced by EGF, tumour necrosis factor $\alpha$ or the peroxisome proliferator nafenopin. European Journal of Biochemistry, 267, 4624-4634. http://dx.doi.org/10.1046/j.1432-1327.2000.01487.x

Deng, H., He, F., \& Zhang, S. (1993). Quantitative measurements of vibration threshold in healthy adults and 
acrylamide workers. International Archives of Occupational and Environmental Health, 65, 53-56. http://dx.doi.org/10.1007/BF00586059

Dixit, R., Seth, P. K., \& Mukjtar, H. (1982). Metabolism of acrylamide into urinary mercapturic acid and cysteine conjugates in rats. Drug Metabolism and Disposition, 10, 196-197.

Douglas, K. T. (1987). Mechanism of action of glutathione-dependent enzymes. Advances in Enzymology and Related Areas of Molecular Biology, 59, 103-167.

Dunn, B. M. (1989). Determination of protease mechanism. In R. Bond \& J. Beynon (Eds.), Proteolytic Enzymes: a practical approach (pp. 57-81). Oxford: Oxford University Press.

Elchuri, S., Oberley, T. D., Qi, W., Eisenstein, R. S., Jackson, R. L., Van Remmen, H., ... Huang, T. T. (2005). $\mathrm{Cu}, \mathrm{Zn}$-SOD deficiency leads to persistent and widespread oxidative damage and hepatocarcinogenesis later in life. Oncogene, 24, 367-380. http://dx.doi.org/10.1038/sj.onc.1208207

Ferrari, D. M., \& Söling, H. D. (1999). The protein disulphide-isomerase family: unravelling a string of folds. Biochemistry Journal, 339, 1-10. http://dx.doi.org/10.1042/0264-6021:3390001

Fountoulakis, M., Berndt, P., Boelsterli, U. A., Crameri, F., Winter, M., Albertini, S., \& Suter, L. (2000). Two-dimentional database of mouse liver proteins: changes in hepatic protein levels following treatment with acetaminophen or its nontoxic regioisomer 3-acetamidophenol. Electrophoresis, 21, 2148-2161. http://dx.doi.org/10.1002/1522-2683(20000601)21:11<2148::AID-ELPS2148>3.0.CO;2-X

Freedman, R. B., Klappa, P., \& Ruddock, L. W. (2002). Protein disulfide isomerases exploit synergy between catalytic and specific binding domains. European Molecular Biology Organization Reports, 3, 136-140. http://dx.doi.org/10.1093/embo-reports/kvf035

Fridovich, I. (1978). The biology of oxygen radicals. Science, 201, 875-880. http://dx.doi.org/10.1126/science.210504

Fujita, T., Uchida, K., \& Maruyama, N. (1992a). Purification of senescence marker protein-30 (SMP30) and its androgen-independent decrease with age in the rat liver. Biochimicaet Biophysica Acta, 1116, 122-128. http://dx.doi.org/10.1016/0304-4165(92)90108-7

Fujita, T., Shirasawa, T., Uchida, K., \& Maruyama, N. (1992b). Isolation of cDNA clone encoding rat senescence marker protein-30 (SMP30) and its tissue distribution. Biochimicaet Biophysica Acta, 1132, 297-305. http://dx.doi.org/10.1016/0167-4781(92)90164-U

Fujita, T., Inoue, H., Kitamura, T., Sato, N., Shimosawa, T., \& Maruyama, N. (1998). Senescence marker protein-30 (SMP30) rescues cell death by enhancing plasma membrane $\mathrm{Ca}^{2+}$-pumping activity in Hep G2 cells. Biochemical and Biophysical Research Communications, 250, 374-380. http://dx.doi.org/10.1006/bbrc.1998.9327

Goldberger, R. F., Epstein, C. J., \& Anfinsen, C. B. (1963). Acceleration of reduced bovine pancreatic ribonuclease by a microsomal system from rat liver. Journal of Biological Chemistry, 238, 628-635.

Hong, M., Cohen, S. D., \& Khairallah, E. A. (1994). Translocation of the major cytosolic acetaminophen (APAP) protein adducts into the nucleus. Toxicologist, 14, 427.

Inoue, H., Fujita, T., Kitamura, T., Shimosawa, T., Nagasawa, R., Inoue, R., ... Nagasawa, T. (1999). Senescence marker protein-30 (SMP30) enhances the calcium efflux from renal tubular epithelial cells. Clinical and Experimental Nephrology, 3, 261-267. http://dx.doi.org/10.1007/s101570050045

Ishida, T., Ishii, Y., Yamada, H., \& Ogur, K. (2002). The Induction of Hepatic Selenium-Binding Protein by Aryl Hydrocarbon (Ah)-Receptor Ligands in Rats. Journal of Health Science, 48, 62-68. http://dx.doi.org/10.1248/jhs.48.62

Kajuus, H., Hansteen, I. L., Ryberg, D., Goffeng, L. O., \& Skaug, V. (2005). Chromosome aberrations in tunnel workers exposed to acrylamide and n- methylolacrylamide. Scandinavian Journal of Work, Environment \& Health, 31, 300-306. http://dx.doi.org/10.5271/sjweh.886

Kellokumpu, S., Suokas, M., Risteli, L., \& Myllyla, R. (1997). Protein disulfide isomerase and newly synthesized procollagen chains form higher-order structures in the lumen of the endoplasmic reticulum. The Journal of Biological Chemistry, 272, 2770-2777. http://dx.doi.org/10.1074/jbc.272.5.2770

Kong, S. K., Fung, K. P., Choy, Y. M., \& Lee, C. Y. (1997). Slow increase in intranuclear and cytosolic free calcium concentrations in L929 cells is important in tumour necrosis factor-alpha-mediated cell death. 
Oncology, 54, 55-62. http://dx.doi.org/10.1159/000227662

Koshikawa, N., Hasegawa, S., Nagashima, Y., Mitsuhashi, K., Tsubota, Y., Miyata, S., .. Miyazaki, K. (1998). Expression of trypsin by epithelial cells of various tissues, leukocytes, and neurons in human and mouse. American Journal of Pathology, 153, 937-944. http://dx.doi.org/10.1016/S0002-9440(10)65635-0

Koyama, N., Sakamoto, H., Sakuraba, M., Koizumi, T., Takashima, Y., Hayashi, M., ... Honma, M. (2006). Genotoxicity of acrylamide and glycidamide in human lymphoblastoid TK6 cells. Mutation Research, 603, 151-158. http://dx.doi.org/10.1016/j.mrgentox.2005.11.006

Laemmli, U. K. (1970). Cleavage of structural proteins during the assembly of the head of bacteriophage T4. Nature, 227, 680-685. http://dx.doi.org/10.1038/227680a0

Larsen, G. L., Bergman, A., \& Klasson-Wehler, E. (1990). A methylsulphonyl metabolite of a polychlorinated biphenyl can serve as a ligand for alpha $2 \mathrm{u}$-globulin in rat and major-urinary-protein in mice. Xenobiotica, 20, 1343-1352. http://dx.doi.org/10.3109/00498259009046632

Lawry, O. H., Roserbrough, N. J., Farr, A. L., \& Randall, R. J. (1951). Protein measurement with the folin phenol reagent. The Journal of Biological Chemistry, 193, 265-275.

Li, S., Cui, N., Zhang, C., Zhao, X., Su-fang, Y., \& Xie, K. (2006). Effect of subchronic exposure to acrylamide induced on the expression of bcl-2, bax and caspase-3 in the rat nervous system. Toxicology, 217, 46-53. http://dx.doi.org/10.1016/j.tox.2005.08.018

Litwack, G., Ketterer, B., \& Arias, I. M. (1971). Ligandin: a hepatic binding protein which binds steroids, bilirubin, carcinogens and a number of exogenous organic anions. Nature, 234, 466-467. http://dx.doi.org/10.1038/234466a0

Marikovsky, M., Ziv, V., Nevo, N., Harris-Cerruti, C., \& Mahler, O. (2003). Cu/Zn superoxide dismutase plays important role in immune response. Journal of Immunology, 170, 2993-3001.

Neurath, H. (1984). Evolution of proteolytic enzymes. Science, 224, 350-357. http://dx.doi.org/10.1126/science.6369538

Nesterova, E. V., Durnev, A. D., \& Seredenin, S. B. (1999). Cytogenetic effects of acrylamide, acrylonitrile and their combination with verapamil in vivo. Bulletin of Experimental Biology and Medicine, 128, 1254-1258. http://dx.doi.org/10.1007/BF02434833

Odland, L., Romert, L., Clemedson, C., \& Walum, E. (1994). Glutathione content, glutathione transferase activity and lipid peroxidation in acrylamide-treated neuroblastoma N1E 115 cells. Toxicology in Vitro, 8, 263-267. http://dx.doi.org/10.1016/0887-2333(94)90192-9

Phillips, W. E., Hoppner, K., Murray, T., \& Campbell, J. (1969). Ubiquinone levels of human liver in health and disease. Canadian Journal of Physiology and Pharmacology, 47, 227-231. http://dx.doi.org/10.1139/y69-042

Porat, A., Sagiv, Y., \& Elazar, Z. (2000). A 56-kDa selenium-binding protein participates in intra-Golgi protein transport. Journal of Biological Chemistry, 275, 14457-14465. http://dx.doi.org/10.1074/jbc.275.19.14457

Robertson, D., Cox, K. A., Gaskell, S. J., Evershed, R., \& Beynon, R. (1996). Molecular heterogeneity in the major urinary proteins of the house mouse Mus musculus. Biochemical Journal, 316, 265-272.

Shahan, K., Denaro, M., Gilmartin, M., Shi, Y., \& Derman, E. (1987). Expression of six mouse major urinary protein genes in the mammary, parotid, sublingual, submaxillary, and lachrymal glands and in the liver. Journal of Molecular Cell Biology, 7, 1947-1954.

Sumner, S. C., MacNeela, J. P., \& Fennell, T. R. (1992). Characterization and quantitation of urinary metabolites of [1,2,3-13C] acrylamide in rats and mice using carbon-13 nuclear magnetic resonance spectroscopy. Chemical Research in Toxicology, 5, 81-90. http://dx.doi.org/10.1021/tx00025a014

Sugimura, T., Okabe, K., \& Baba, T. (1962). Studies on ubiquinone (coenzyme Q) in neoplastic tissues. Gann, $53,171-181$.

Shichiri, M., Shigeta, Y., Abe, H., Izumi, K., Redalieu, E., \& Folkers, K. (1968). Apparent low levels of ubiquinone in rat and human neoplastic tissues. International Journal for Vitamin, 38, 473-481.

Tareke, E., Rydberg, P., Karlsson, P., Eriksson, S., \& Törnqvist, M. (2002). Analysis of acrylamide, a carcinogen formed in heated foodstuffs. Journal of Agricultural and Food Chemistry, 50, 4998-5006. http://dx.doi.org/10.1021/jf020302f 
Timm, D. E., Baker, L. J., Mueller, H., Zidek, L., \& Novotny, M. V. (2001). Structural basis of pheromone binding to mouse major urinary protein (MUP-I). Protein Sciences, 10, 997-1004. http://dx.doi.org/10.1110/ps.52201

Tsuda, H, Chimizu, C., Taketomi, M., Hasegawa, M. M., Hamada, A., Kawata, K. M., \& Inui, N. (1993). Acrylamide induction of DNA damage, chromosomal aberrations and cell transformation without gene mutations. Mutagen, 8, 23-29. http://dx.doi.org/10.1093/mutage/8.1.23

World Health Organization (WHO). (2003). Acrylamide in drinking water. Retrieved from http://www.who.int/water_sanitation_health/dwq/chemicals/0304_71/en/index $9 . h t m l$

Xue, J. H., Takahashi, H., \& Yamaguchi, M. (2000). Stimulatory effect of regucalcin on mitochondrial ATP-dependent calcium uptake activity in rat kidney cortex. Journal of Cellular Biochemistry, 80, $285-292$. http://dx.doi.org/10.1002/1097-4644(20010201)80:2<285::AID-JCB180>3.0.CO;2-5

Yang, M., \& Sytkowski, A. J. (1998). Differential expression and androgen regulation of the human selenium-binding protein gene HSP56 in prostate cancer cells. Cancer Research, 58, 3150-3153.

Yamamoto, Y., \& Tanaka, S. (1967). Catabolism of cholesterol in a rat transplanted with walker carcinoma and the interrelation with 0-carotene and ubiquinone. Gann, 58, 147-154.

Yi, C., Xie, K., Song, F., Yu, L., Zhao, X., Li, G., \& Yu, S. (2006). The changes of cytoskeletal proteins in plasma of acrylamide-induced rats. Neurochemical Research, 31, 751-757. http://dx.doi.org/10.1007/s11064-006-9079-x

Yousef, M. I., \& El-Demerdash, F. M. (2006). Acrylamide-induced oxidative stress and biochemical perturbations in rats. Toxicology, 219, 133-141. http://dx.doi.org/10.1016/j.tox.2005.11.008

\section{Copyrights}

Copyright for this article is retained by the author(s), with first publication rights granted to the journal.

This is an open-access article distributed under the terms and conditions of the Creative Commons Attribution license (http://creativecommons.org/licenses/by/3.0/). 